\title{
Regulatory $T$ and $B$ Cells in Asthmatic Women: Variations From Pregnancy to Postpartum
}

\author{
Martins $\mathrm{C}^{1}$, Lima J ${ }^{1,2}$, Nunes $\mathrm{G}^{1}$, Borrego $\mathrm{LM}^{1,3}$ \\ ${ }^{1}$ CEDOC, Chronic Diseases Research Center, NOVA Medical School|FCM; Universidade Nova de Lisboa, Lisbon, \\ Portugal \\ ${ }^{2}$ Ginecologia e Obstetrícia, Hospital CUF Descobertas, Lisbon, Portugal \\ ${ }^{3}$ Imunoalergologia, Hospital CUF Descobertas, Lisbon, Portugal
}

J Investig Allergol Clin Immunol 2017; Vol. 27(1): 46-57

doi: 10.18176/jiaci.0086

\begin{abstract}
Background and Objectives: Allergic asthma and rhinitis are common in pregnancy. The immune mechanisms underlying the effects of asthma on pregnancy and vice versa are not completely understood. The aim of this study was to investigate changes in regulatory $T$ and B cells in asthmatic women from late pregnancy to postpartum.

Methods: Four groups of women were enrolled for this study: asthmatic $(n=23)$ and healthy $(n=43)$ third trimester-pregnant women and asthmatic $(n=33)$ and healthy $(n=35)$ nonpregnant women. Pregnant women were also evaluated postpartum ( $>6$ weeks after delivery). Blood samples were taken from each woman and flow cytometry was used to characterize circulating regulatory $T$ cells (Tregs) and regulatory B cells (Bregs). Foxp3 expression was assessed in CD4 ${ }^{\text {Dim }}$ CD25 ${ }^{\text {Hi }}$ Tregs.

Results: Tregs did not vary significantly from pregnancy to postpartum in asthmatic or healthy women, but CD24 ${ }^{\text {Hi }} \mathrm{CD} 38^{\mathrm{Hi}} \mathrm{Bregs}$ decreased in pregnancy and increased significantly postpartum. Foxp3 expression in Tregs was also impaired during pregnancy in both asthmatic and healthy women, but recovered postpartum. Asthmatic pregnant women had higher Foxp3 expression levels than healthy pregnant women $(P=.007)$, probably due to the use of control medication.

Conclusions: Women with controlled asthma showed variations in regulatory cell subsets during pregnancy and postpartum. A similar pattern was observed for Foxp3 expression and $\mathrm{CD} 24^{\mathrm{Hi}} \mathrm{CD} 38^{\mathrm{Hi}}$ Bregs during this period, corroborating the interaction between Tregs and Bregs in immune responses. Considering the immunomodulatory potential of these immune mediators, more studies are needed to evaluate their relationship with asthma and rhinitis complications in pregnancy.
\end{abstract}

Key words: Atopy. Gestation. Postpartum. Regulatory T-Cells. Regulatory B-Cells. Humans. Flow cytometry.

\section{Resumen}

Introducción y Objetivos: El asma y la rinitis alérgica son enfermedades comunes durante el embarazo. A pesar de ello, no están completamente esclarecidos los mecanismos inmunológicos del embarazo implicados en el asma y viceversa. Este trabajo tuvo como objetivo el estudiar la evolución de los linfocitos T y B reguladores en mujeres asmáticas embarazadas, desde fases tardías del embarazo hasta después del parto.

Métodos: Se incluyeron cuatro grupos de mujeres para este estudio: mujeres embarazadas en su tercer trimestre, asmáticas ( $\mathrm{n}=24)$ y sanas $(n=43)$, y mujeres no embarazadas, asmáticas $(n=33)$ y sanas $(n=35)$. Las mujeres embarazadas también fueron evaluadas después del parto (> 6 semanas después del parto). Se tomaron muestras de sangre de cada mujer y se realizó citometría de flujo para caracterizar los linfocitos T y B reguladores circulantes. La expresión de Foxp3 se evaluó en los linfocitos T reguladores CD4 ${ }^{\mathrm{Dim}}$ CD25 $5^{\mathrm{Hi}}$. Resultados: En las mujeres embarazadas, tanto sanas como asmáticas, los linfocitos T reguladores no oscilaron de manera significativa desde el embarazo hasta después del parto. Sin embargo, en los linfocitos B reguladores CD24 ${ }^{\mathrm{Hi} C D} 38^{\mathrm{Hi}}$, se observó una disminución durante el embarazo que aumentó significativamente después del parto. La expresión de Foxp3 en los linfocitos T reguladores también se vio alterada durante el embarazo tanto en las mujeres embarazadas asmáticas como en las sanas, normalizándose en el posparto. No obstante, las mujeres asmáticas embarazadas presentaron niveles de expresión de Foxp3 superiores a los de las mujeres embarazadas sanas $(p=0,007)$, probablemente debido a la utilización de medicación de control. 
Conclusiones: Las mujeres con asma controlada, durante el embarazo y después del parto, presentan variaciones en los diferentes subtipos linfocitos reguladores. El similar comportamiento que se observa para la expresión de Foxp3 y los linfocitos B reguladores CD24 ${ }^{\mathrm{Hi} C D 38^{\mathrm{Hi}}}$ apoya la interacción que se establece en la respuesta inmunitaria, entre los linfocitos T y B reguladores, durante este período. Teniendo en cuenta el potencial inmunomodulador de estos mecanismos, se necesitan más estudios para evaluar su relación con las complicaciones del asma y la rinitis durante el embarazo.

Palabras clave: Atopia. Embarazo. Posparto. Linfocitos humanos T reguladores. Linfocitos humanos B reguladores. Citometría de flujo.

\section{Introduction}

Allergic asthma and rhinitis can present risks for pregnancy [1]. Disease manifestations may improve, remain unchanged, or worsen during this period, and asthma exacerbations can have a significant impact on fetal development and birth weight and have also been linked to preterm delivery [1]. In addition, maternal asthma is a risk factor for the development of asthma in offspring [2].

Pregnancy challenges the immune system, as it must develop tolerance towards the semi-allogenic fetus, without compromising the mother's defenses. Type 2 helper $\mathrm{T}\left(\mathrm{T}_{\mathrm{H}} 2\right)$ cells, a hallmark of atopic diseases, are typically associated with gestation and appear to contribute to the maintenance of pregnancy [3]. Nonetheless, in addition to generating a biased $\mathrm{T}_{\mathrm{H}} 2$ immune response, pregnancy also appears to be associated with strict regulatory mechanisms that balance cytokine production [4].

Regulatory T cells (Tregs), which are known to increase during early pregnancy [5], seem to be decreased and/or functionally impaired in asthmatics [6,7]. Yet, Tregs and IL-10, an anti-inflammatory cytokine secreted by these cells, have been implicated in the improvement of asthma [8]. In a recent study, B cells were attributed an important role in $\mathrm{T}_{\mathrm{H}} 2$ responses and airway inflammation [9]. Impaired regulatory activity has also been reported for regulatory B cells (Bregs) in allergic asthma [10], and these cells are closely related to Tregs [11].

Modifications to T- and B-cell subsets have been reported in healthy [12-14] and asthmatic [15,16] women during pregnancy. However, not much is known about B cells or about the immune profile in the postpartum period, in which an immune reactivation is believed to occur [17].

The aim of this study was to characterize Treg, Breg, and IL-10 expression in asthmatic women from late pregnancy to postpartum and to analyze the impact of pregnancy on these immune parameters.

\section{Methods}

\section{Study Participants}

Pregnant and nonpregnant women of reproductive age with or without atopic asthma seen at Hospital CUF Descobertas in Lisbon, Portugal were consecutively enrolled for this study. The women were divided into 4 groups: asthmatic pregnant (AP) women, healthy pregnant (HP) women, asthmatic nonpregnant (ANP) women, and healthy nonpregnant (HNP) women. They were all informed about the nature of the study and provided written informed consent at recruitment. Blood samples were collected once (at recruitment) for nonpregnant women and twice for pregnant women: once during the third trimester of gestation (weeks 31-36) and again during the postpartum period (at least 6 weeks after delivery). All the women completed questionnaires on demographic and clinical data at each time point. Exclusion criteria for all the groups were diabetes; hypertension; autoimmune diseases; active infectious diseases, including hepatitis and HIV; any other respiratory or allergic disease (except atopic dermatitis and allergic rhinitis); and smoking during the 6 months before sample collection. Additional exclusion criteria for HP women were multiple gestation, pregnancy complications, and prenatal use of any medications (other than vitamins, folic acid, and iron supplements). The same criteria, with the exception of treatments for atopic disease, were applied to AP women.

Women in the AP and ANP groups had physiciandiagnosed atopic asthma and rhinitis according to current international guidelines [18-20], with documented sensitization to aeroallergens by skin prick tests and/or specific $\operatorname{IgE}$ quantification. Current and past immunotherapy were considered exclusion criteria. Asthma and rhinitis were treated according to current guidelines [19,20]. All the asthmatic women were receiving low to medium doses of inhaled corticosteroids (ICSs) (200-400 $\mu \mathrm{g}$ beclomethasone daily) and/or long-acting $\beta$-agonists (LABA) and antileukotrienes. None had had an asthma exacerbation for at least 6 weeks before the first sample collection. Asthma symptoms were evaluated according to the Global Initiative for Asthma guidelines $[19,20]$, and level of disease control was assessed on the basis of daytime symptoms, night waking due to asthma, need for reliever, and activity limitation due to asthma. Table 1 summarizes the demographic and anthropometric data for the 4 groups of women.

The study was approved by the ethics committees at Hospital CUF Descobertas and NOVA Medical School. All investigations were conducted according to the principles of the Declaration of Helsinki.

\section{Tregs and Bregs}

Peripheral blood samples were collected in EDTAcontaining tubes using standard aseptic venipuncture techniques. Cells were processed within a maximum of 24 hours of collection.

The Human FoxP3 Buffer Set (BD Pharmingen) was used for Treg phenotyping according to the manufacturer's 
Table 1. Demographic and Anthropometric Comparisons Between Pregnant and Nonpregnant Women With and Without Asthma

\begin{tabular}{|c|c|c|c|c|c|}
\hline & $\begin{array}{l}\text { AP Women } \\
n=24\end{array}$ & $\begin{array}{l}\text { ANP Women } \\
n=32\end{array}$ & $\begin{array}{l}\text { HP Women } \\
n=43\end{array}$ & $\begin{array}{l}\text { HNP Women } \\
\quad \mathrm{n}=35\end{array}$ & $P$ Value \\
\hline Maternal age, median (IQR), y & $34(4)$ & $36(6)$ & $32(5)$ & $35(4)$ & $.063^{\mathrm{a}}$ \\
\hline $\begin{array}{l}\text { Ethnicity, No. (\%) } \\
\text { White } \\
\text { Black }\end{array}$ & $\begin{array}{l}24(100.0) \\
0(0.0)\end{array}$ & $\begin{array}{l}32(100.0) \\
0(0.0)\end{array}$ & $\begin{aligned} 42 & (97.7) \\
1 & (2.3)\end{aligned}$ & $\begin{array}{l}35(100.0) \\
0(0.0)\end{array}$ & $.545^{\mathrm{b}}$ \\
\hline Body mass index, median (IQR), $\mathrm{kg} / \mathrm{m}^{2}$ & $26.2(4.5)$ & $21.9(5.0)$ & $25.6(4.1)$ & $21.1(2.4)$ & $<.001^{\mathrm{a}}$ \\
\hline $\begin{array}{l}\text { Education, No. }(\%) \\
\text { Primary/secondary } \\
\text { Higher education }\end{array}$ & $\begin{array}{c}2(8.3) \\
22(91.7)\end{array}$ & $\begin{array}{c}5(16.1) \\
26(83.9)\end{array}$ & $\begin{array}{c}4(9.3) \\
39(90.7)\end{array}$ & $\begin{array}{c}7(2.3) \\
23(76.7)\end{array}$ & $.296^{\mathrm{b}}$ \\
\hline $\begin{array}{l}\text { Parity, No. }(\%) \\
\text { Nuliparous } \\
\text { Multiparous }\end{array}$ & $\begin{array}{l}12(50.0) \\
12(50.0)\end{array}$ & - & $\begin{array}{l}24(55.8) \\
19(44.2)\end{array}$ & - & $.799^{\mathrm{d}}$ \\
\hline $\begin{array}{l}\text { Smoke exposure during pregnancy, No. }(\%) \\
\text { Yes } \\
\text { No }\end{array}$ & $\begin{array}{c}3(12.5) \\
22(91.7)\end{array}$ & - & $\begin{array}{c}7(16.3) \\
36(83.7)\end{array}$ & - & $>.999^{d}$ \\
\hline $\begin{array}{l}\text { Gestational age (complete weeks) } \\
\text { at evaluation, mean (SD) }\end{array}$ & $33(0.9)$ & - & $33(1.1)$ & - & $.265^{\mathrm{c}}$ \\
\hline $\begin{array}{l}\text { Gestational age (complete weeks) } \\
\text { at parturition, mean (SD) }\end{array}$ & $39(1.1)$ & - & $39(1.1)$ & - & $.296^{\mathrm{c}}$ \\
\hline Weight at birth, mean (SD), g & $3262(329)$ & - & $3199(402)$ & - & $.493^{\mathrm{c}}$ \\
\hline $\begin{array}{l}\text { Sex of newborn, No. }(\%) \\
\quad \text { Male } \\
\text { Female }\end{array}$ & $\begin{array}{l}12(50.0) \\
12(50.0)\end{array}$ & - & $\begin{array}{l}21(48.8) \\
22(51.2)\end{array}$ & - & $>.999^{d}$ \\
\hline Time of blood collection postpartum, median (IQR) & $44(8)$ & - & $44(5)$ & - & $.589^{\mathrm{b}}$ \\
\hline $\begin{array}{l}\text { Breast feeding, No. }(\%) \\
\text { Yes } \\
\text { No }\end{array}$ & $\begin{array}{c}23(95.8) \\
1(4.2)\end{array}$ & - & $\begin{array}{l}33(76.7) \\
10(23.3)\end{array}$ & - & $.082^{\mathrm{d}}$ \\
\hline $\begin{array}{l}\text { Sensitization to aeroallergens, No. (\%) } \\
\text { Dermatophagoides pteronyssinus } \\
\text { Dermatophagoides farinae } \\
\text { Lepidoglyphus destructor } \\
\text { Grass pollens }\end{array}$ & $\begin{aligned} 15 & (62.5) \\
12 & (50.0) \\
2 & (8.3) \\
25 & (20.8)\end{aligned}$ & $\begin{array}{l}21(65.6) \\
18(56.3) \\
9(28.1) \\
14(43.8)\end{array}$ & $\begin{array}{l}- \\
- \\
-\end{array}$ & $\begin{array}{l}- \\
- \\
-\end{array}$ & $\begin{array}{l}>.999^{\mathrm{d}} \\
.788^{\mathrm{d}} \\
.093^{\mathrm{d}} \\
.092^{\mathrm{d}}\end{array}$ \\
\hline
\end{tabular}

Abbreviations: AP, asthmatic pregnant; ANP, asthmatic nonpregnant; HP, healthy nonpregnant; HNP, healthy nonpregnant.

aruskal-Wallis test.

${ }^{b} \chi^{2}$ test.

Unpaired $t$ test.

dFisher exact test.

eMann-Whitney U test.

instructions. First, the cells were lysed with BD FACS Lysing Solution (BD Biosciences) and incubated with anti-CD25 PE (clone BC96, Biolegend) and anti-CD4 PerCP Cy5.5 (clone SK3, Biolegend). After being fixed and permeabilized with the reagents supplied in the kit, the cells were stained with AntiFoxp3 Alexa Fluor 488 (clone 259D/C7, BD Pharmingen). At least $10000 \mathrm{CD}^{+} \mathrm{T}$ cells were acquired.

The panel of monoclonal antibodies (mAbs) used to evaluate Bregs included anti-CD19 PerCP Cy5.5 (clone HIB19, Biolegend), anti-CD24 PE (clone ML5, Biolegend), anti-CD27 FITC (clone O323, Biolegend), and anti-CD38 APC (clone HIT2, Biolegend). A lyse-wash protocol was used. Briefly, cells were incubated with $\mathrm{mAbs}$ for 15 minutes and then lysed with BD FACS Lysing Solution (BD Biosciences). Acquisition was performed after a wash step with phosphate-buffered saline. At least $2000 \mathrm{CD} 19^{+} \mathrm{B}$ cells were acquired.

\section{Cell Culture for Intracellular Cytokine Stimulation}

Heparin whole blood was used to evaluate IL-10 expression in T and B cells. Cells were stimulated with PMA $(50 \mathrm{ng} / \mathrm{mL}$; Sigma Aldrich), calcium ionophore (1 $\mu \mathrm{g} / \mathrm{mL}$, Sigma Aldrich), and lipopolysaccharide (10 $\mu \mathrm{g} / \mathrm{mL}$, Sigma Aldrich) [21], and incubated for 5 hours at $37^{\circ} \mathrm{C}$ in a $5 \% \mathrm{CO} 2$ atmosphere in the presence of Brefeldin A $(1.0 \mu \mathrm{g} / \mathrm{ml}$, BD Pharmingen). For each sample, unstimulated tubes were incubated in parallel, and were further used as stimulation and staining controls. The protocol was performed according to the instructions supplied with the Cytofix-Cytoperm kit (BD Pharmingen). 
A

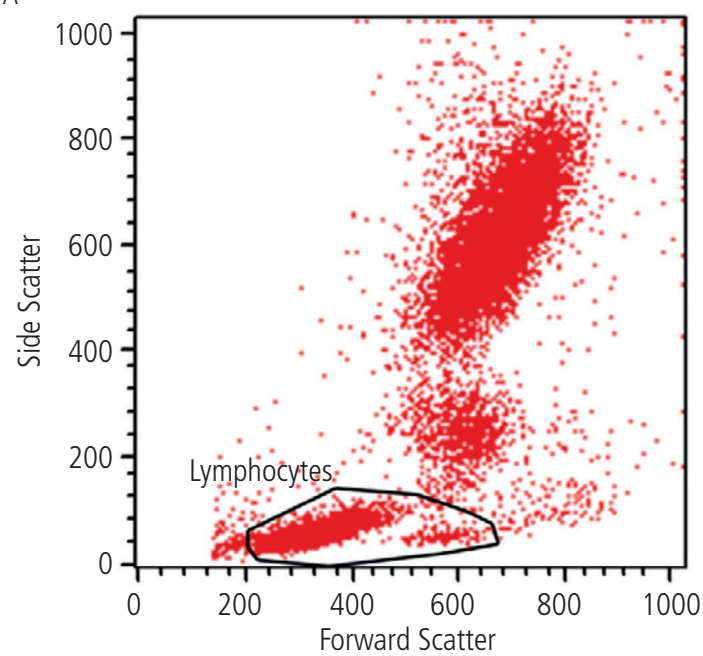

C

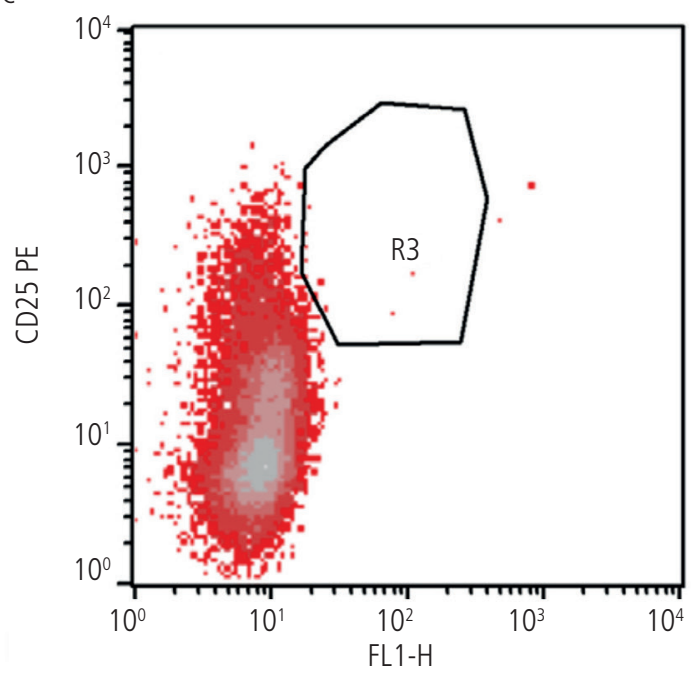

B

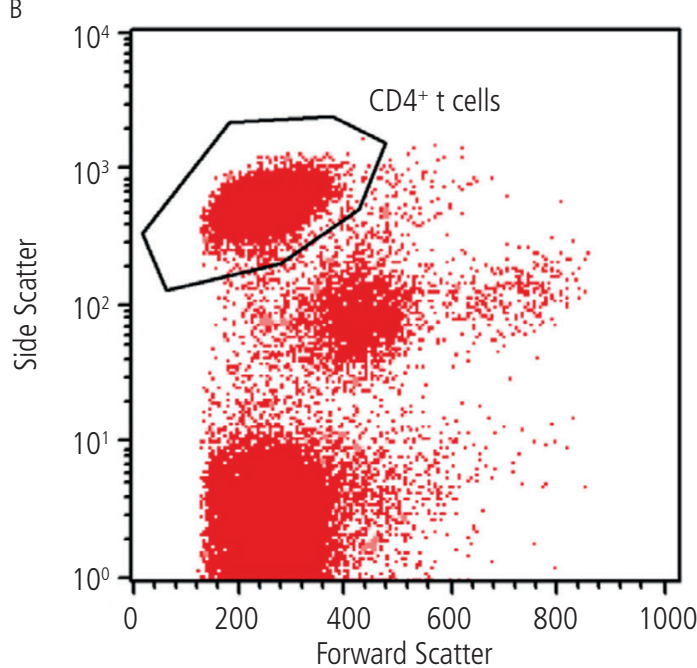

D

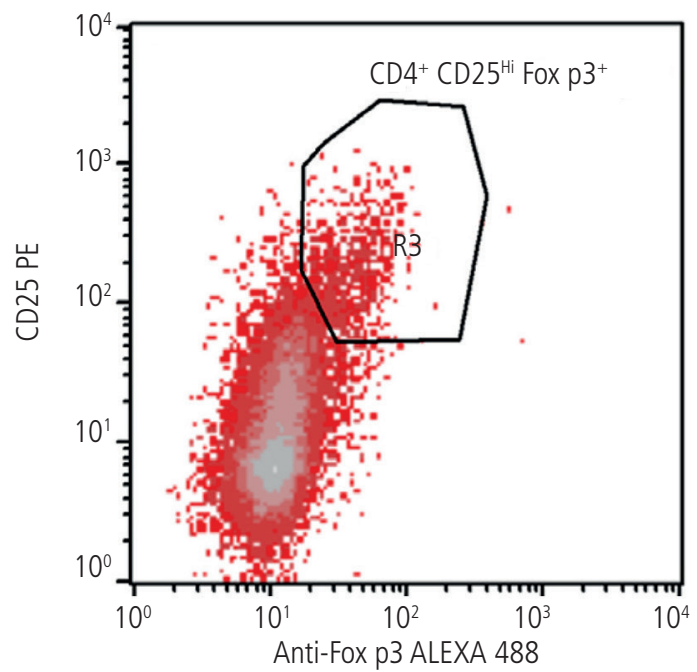

E

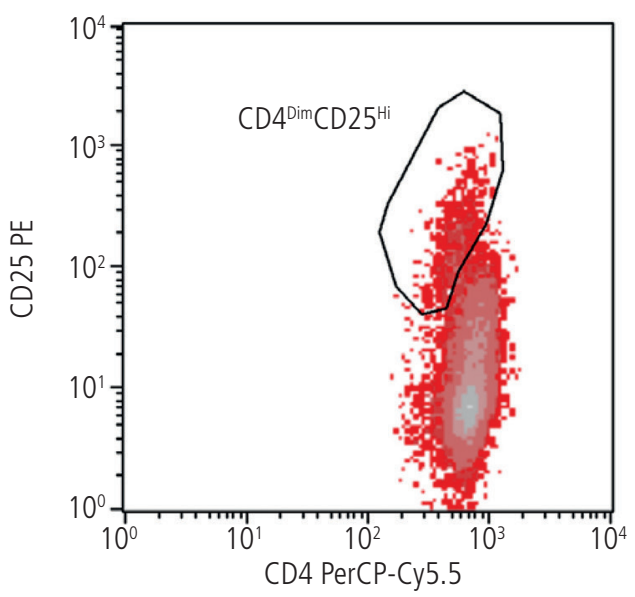

$\mathrm{F}$

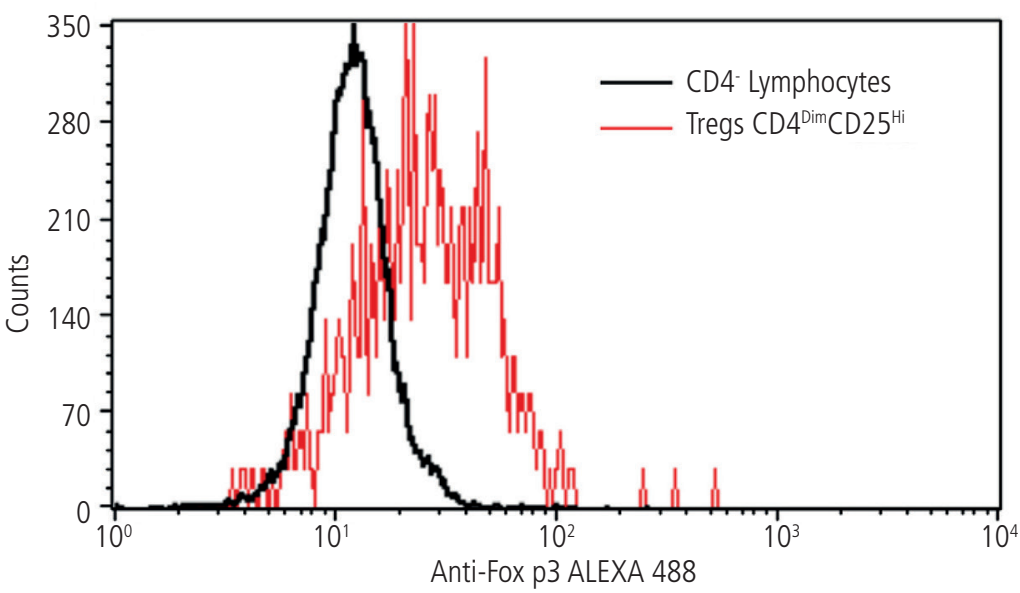

Figure 1. Gating strategies for the identification of distinct regulatory T-cell subsets. A-B, The first step in the analysis of T regulatory cells (Tregs) was the identification of $C D 4^{+} T$ cells, recognized as CD4+ cells within the lymphocyte gate. C-D, Identification of CD4+CD25 HiFoxp3 ${ }^{+}$Tregs with dot plots

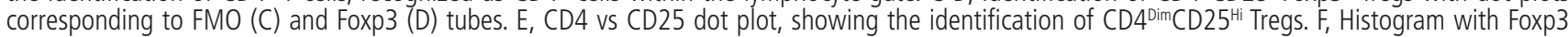
expression within $\mathrm{CD} 4^{\mathrm{Dim}} \mathrm{CD} 25^{\mathrm{Hi}}$ Tregs (gray line), overlying Foxp3 expression within CD4- lymphocytes (black line). Geometric mean MFI values were further transformed into the ratio MFI of Foxp3 in CD4 ${ }^{\text {Dim }}$ CD25 Hi/MFI of Foxp3 in CD4- lymphocytes. 
Briefly, the initial surface staining step included incubation with anti-CD3-FITC (clone SK7, BDBiosciences), anti-CD8 APC (clone SK1, Biolegend), and anti-CD19 PerCP Cy5.5 (clone HIB19, Biolegend). After fixing and permeabilizing, the cells were marked with anti-IL10 PE (clone JES3-19F1, Biolegend). A minimum of $2000 \mathrm{~B}$ cells $\left(\mathrm{CD} 19^{+}\right)$or $10000 \mathrm{~T}$ cells $\left(\mathrm{CD}^{+}\right)$were acquired.

\section{Multicolor Flow Cytometry and Data Analysis}

Flow cytometry was performed in a 4-color BD FACSCalibur (BD Biosciences) equipped with a 488-nm blue laser and a 647-nm red laser. Equipment setup, calibration, and quality control protocols were performed to ensure trough time stability in measurements. Figure 1 presents the gating strategy for Treg assessment and Foxp3 expression (assessed as geometric mean values of mean fluorescence intensity [MFI]
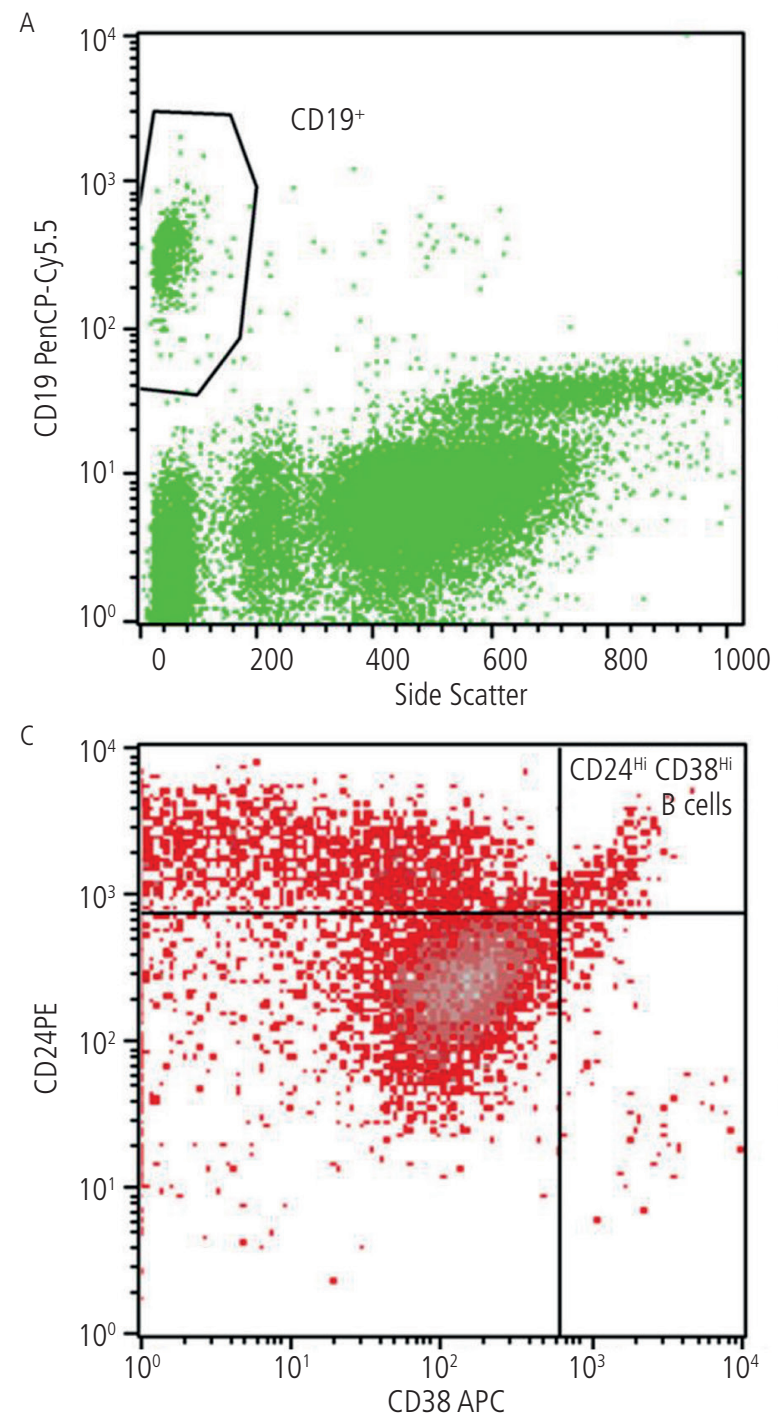

units). To reduce the impact of day-to-day variations, the ratio between the MFI of Foxp3 in CD4 ${ }^{\mathrm{Dim}} \mathrm{CD} 25^{\mathrm{Hi}}$ Tregs and in CD4 lymphocytes was calculated. The gating strategies for Breg subsets and IL-10 secretion are presented in Figures 2 and 3.

All evaluations were performed directly in whole blood.

\section{Statistical Analysis}

Categorical variables were expressed as absolute frequencies and percentages and analyzed using the Fisher exact or $\chi^{2}$ test. Normality of distribution was assessed using the D'Agostino and Pearson test. Normally distributed data are presented as mean (SD) and nonnormally distributed data as median (IQR). Multiple group evaluations were performed using 1-way analysis of variance or the Kruskal-Wallis test, followed by Tukey's and Dunn's multiple comparison tests, respectively. Data for paired groups were analyzed with the

B

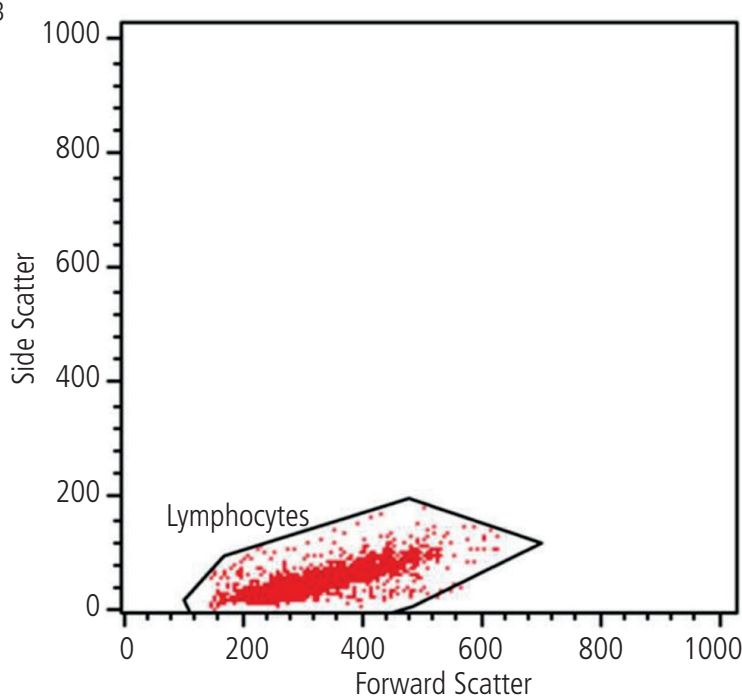

D

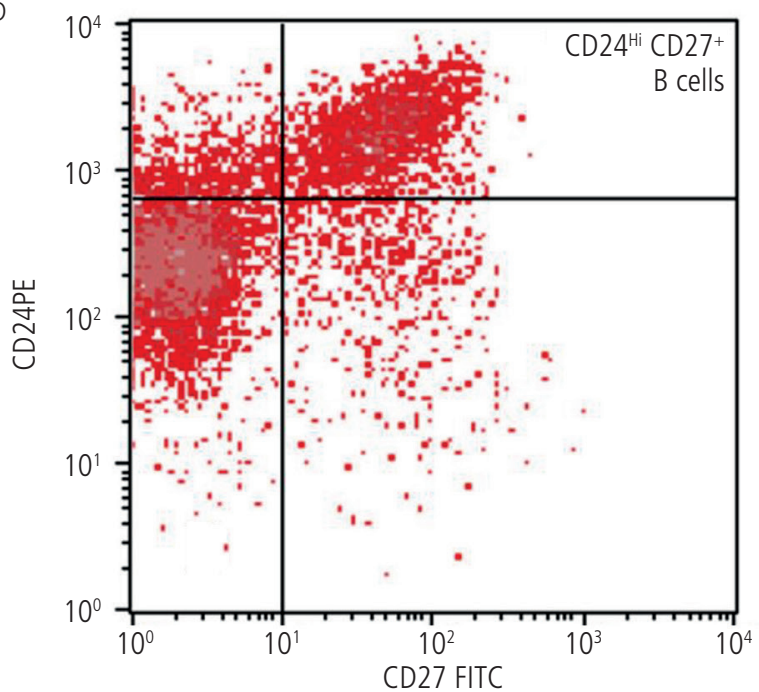

Figure 2. Gating strategies for the identification of distinct regulatory B-cell subsets. B cells were identified as the CD19+ population within the lymphocyte gate, as displayed in dot plots A and B. C and D dot plots show the identification of regulatory B-cell subsets according to their expression of CD24, CD27, and CD38 (CD24 $4^{\mathrm{H}} \mathrm{CD} 27+$ Bregs and CD24 ${ }^{\mathrm{Hi}} \mathrm{CD} 38^{\mathrm{Hi}}$ Bregs). 
A

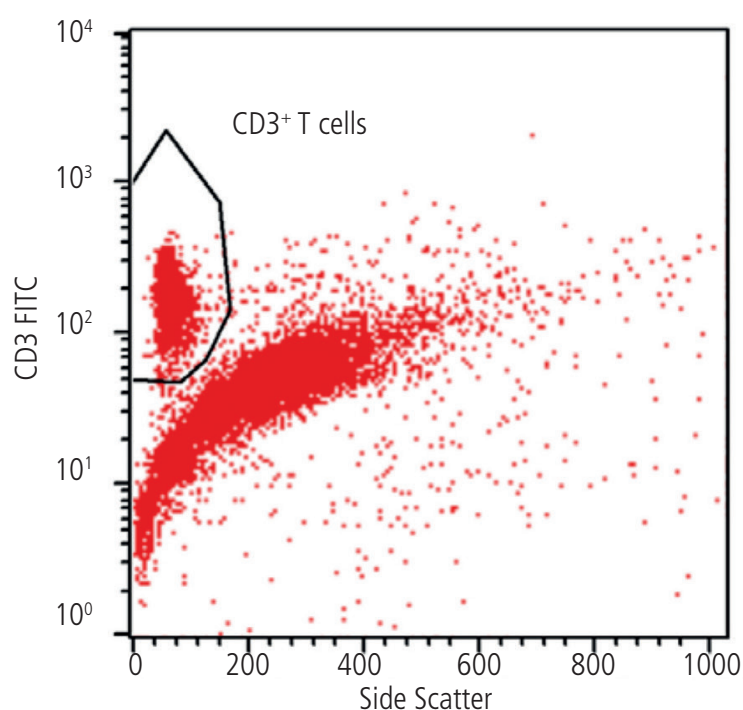

C

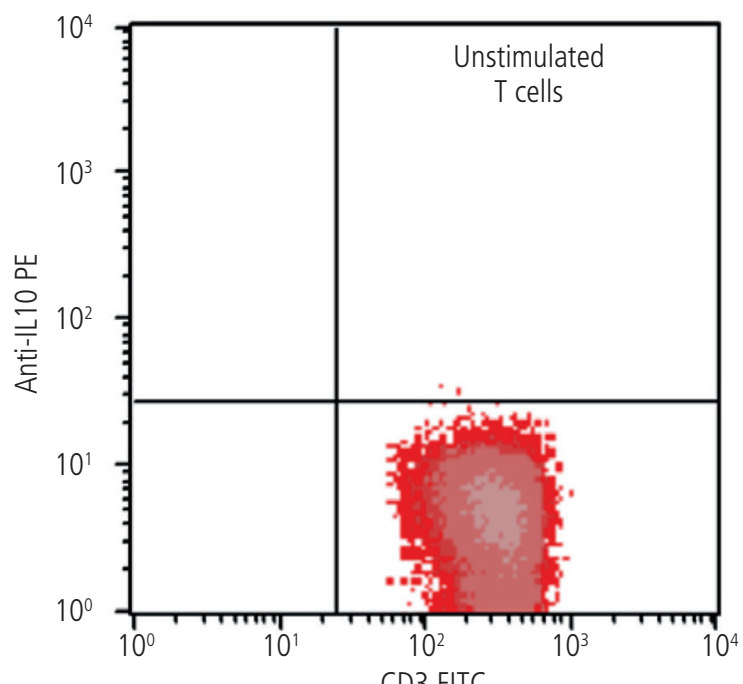

B

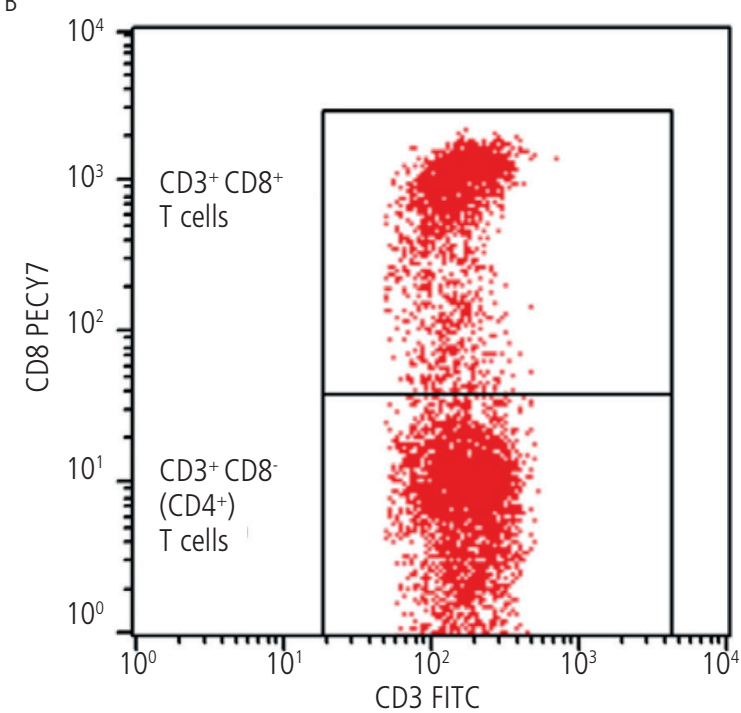

D

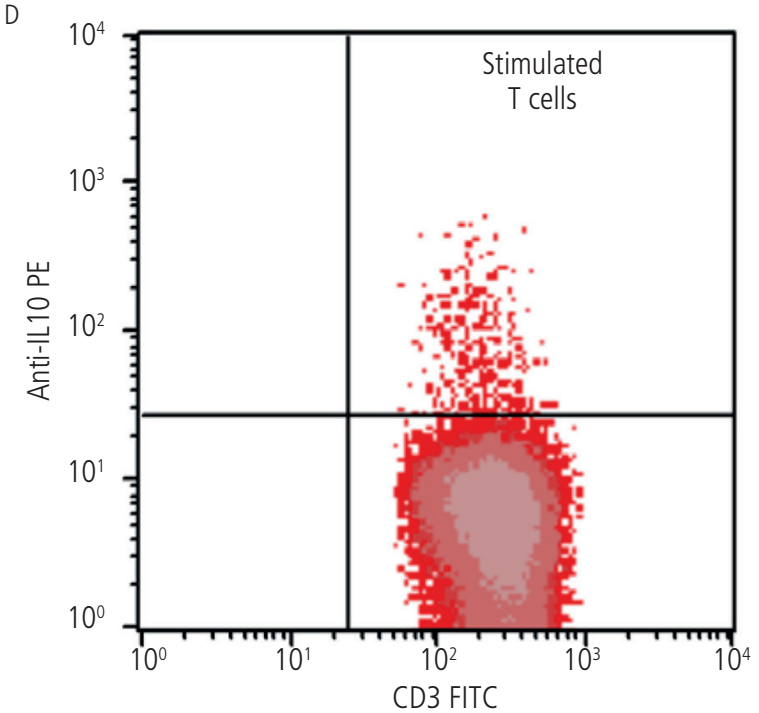

Figure 3. Gating strategies for the identification of IL-10 secretion in T and B cells. A-B, T cells were identified according to their positive expression of CD3 as shown in the CD3/SSC (side scatter) dot plot, and were further gated in CD8 ${ }^{-}$cells (CD4) and CD8 ${ }^{+}$T cells (CD8), according to expression of CD8. C-D, CD19+ B cells (gated as shown in Figure 2) and CD4+ and CD8 ${ }^{+}$T cells (gated as shown in Figure $3-A$ and B) were analyzed for expression of IL-10 after stimulation with PMA+lonomycin and lipopolysaccharide. Unstimulated samples (C) were used to assess the cutoff for the expression of IL-10 after stimulation in $\mathrm{B}$ cells and $\mathrm{CD}^{+}{ }^{+}, \mathrm{CD} 4^{+}$, and $\mathrm{CD} 8^{+} \mathrm{T}$ cells (D).

paired $t$ test or Wilcoxon test. The unpaired $t$ test or MannWhitney test were used to compare each 2 independent groups.

Statistical significance was defined as a $\mathrm{P}$ value of less than .05. All data were analyzed using GraphPad Prism software, version 6.01 for Windows (GraphPad Software, http://www. graphpad.com). Tukey box-and-whiskers graphs, also obtained with GraphPad Prism, were used to present results.

\section{Results}

\section{Demographic and Anthropometric Data}

The demographic and anthropometric results for the 4 groups of women (AP, $n=24 ; A N P, n=32 ; H P, n=43$; and HNP, $\mathrm{n}=35$ ) are summarized in Table 1 . On comparing the groups, the only statistically significant difference was observed for body mass index (BMI). The Kruskal-Wallis test showed a $P$ value, and subsequent Dunn's multiple comparisons also detected significantly higher BMI values in pregnant women $(P<.001$ for HP vs HNP and $P=.001$ for AP vs ANP). The AP and HP women were comparable in terms of parity.

Asthma and/or rhinitis complications are also summarized in Table 1. Four women (16.7\%) reported asthma exacerbations during the third trimester of pregnancy, while $2(8.3 \%)$ reported rhinitis (nasal symptoms). Postpartum, 1 woman $(4.2 \%)$ reported an asthma exacerbation and $2(8.3 \%)$ reported rhinitis (nasal symptoms). None of these complications required hospitalization or treatment at an emergency department. 
A
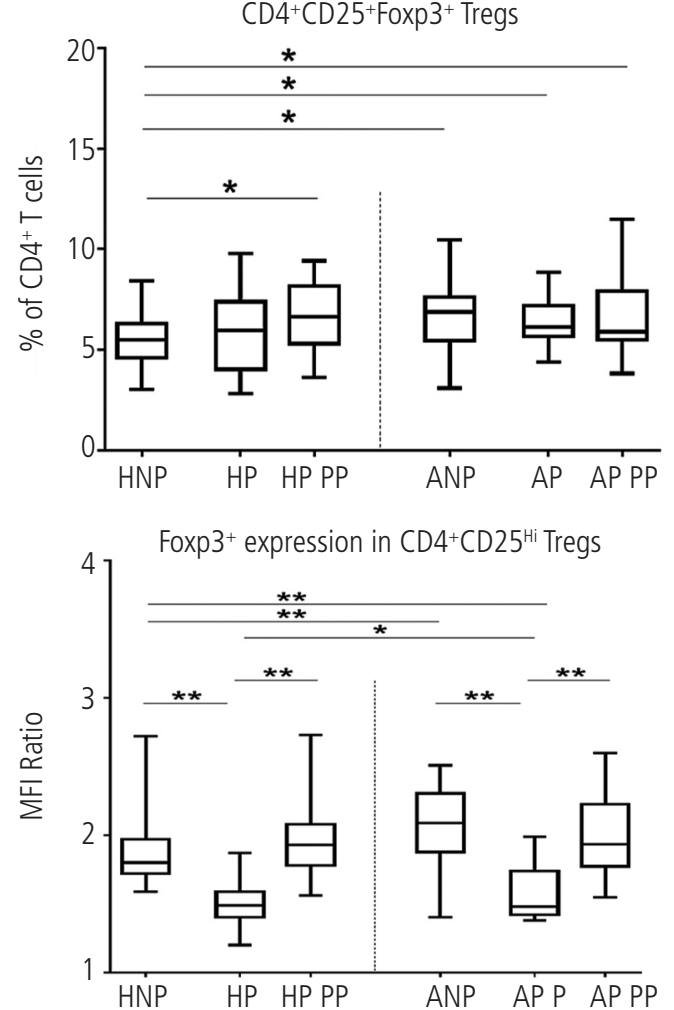

C
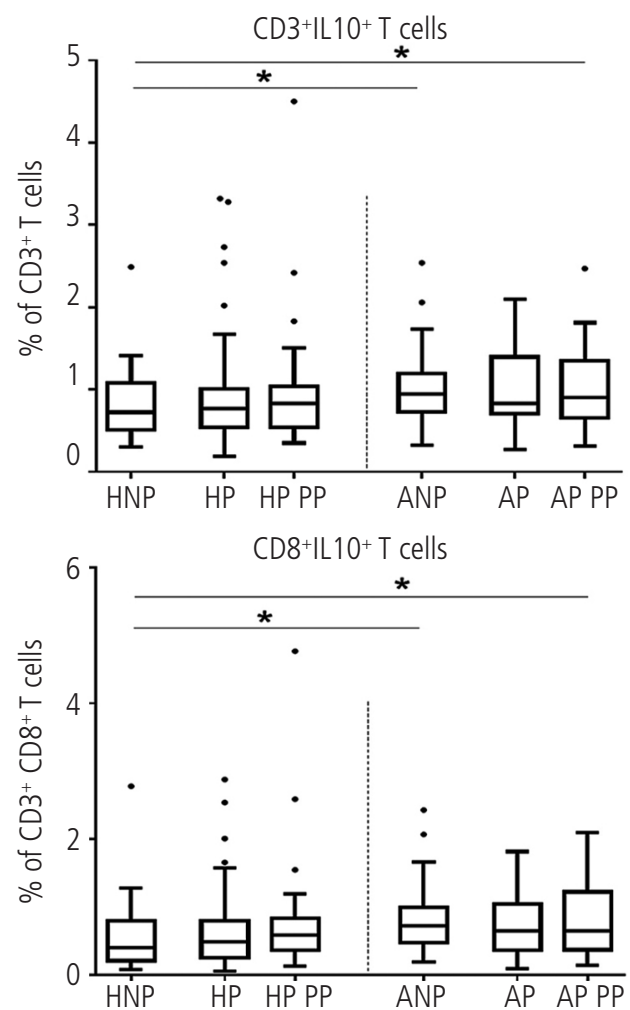

B
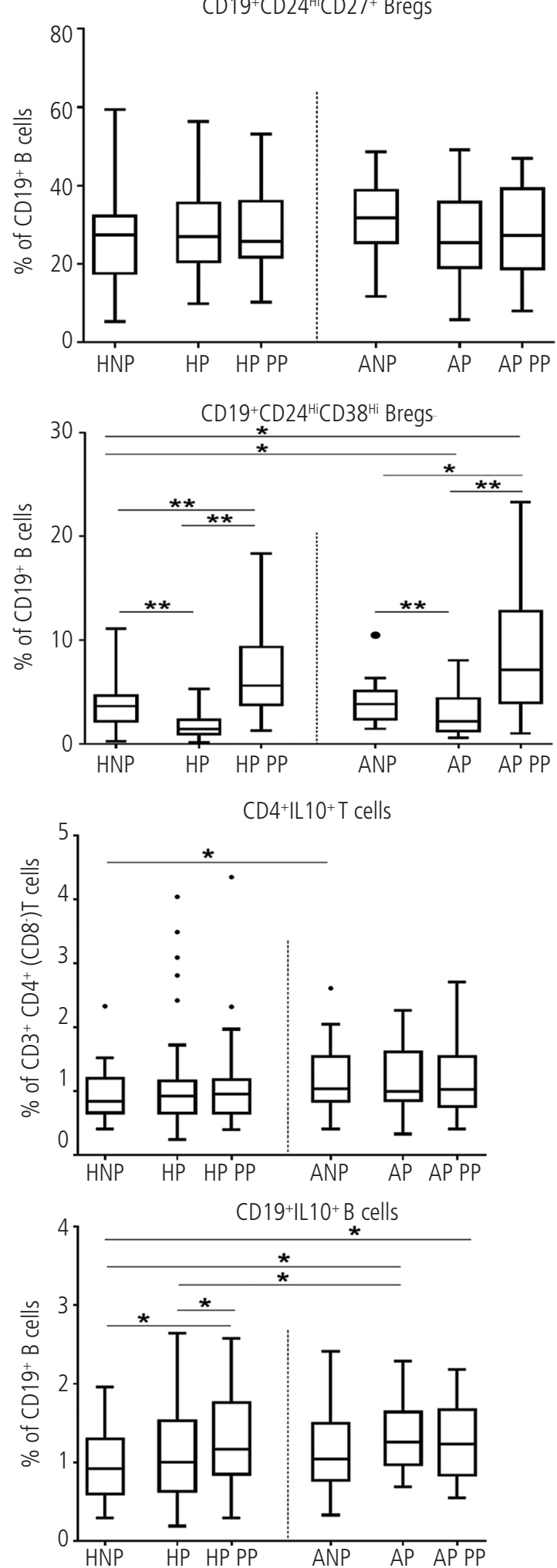

Figure 4. Immune parameters in healthy nonpregnant (HNP), healthy pregnant (HP), asthmatic nonpregnant (ANP), and asthmatic pregnant (AP) women. $A$, Representative Tukey box-and-whisker plots of CD4 ${ }^{+} C D 25^{\text {HiF }}$ oxp3 $3^{+}$regulatory T-cell (Treg) subset frequencies and Foxp3 expression within CD4 ${ }^{\text {Dim }}$ CD25 ${ }^{\text {Hi }}$ Tregs in HNP, HP, ANP, and AP, including postpartum evaluation of pregnant women. B, Representative Tukey box-and-whisker plots of circulating regulatory B-cell (Breg) subset frequencies in HNP, HP, ANP, and AP women, including postpartum (PP) evaluation of pregnant women. C, Representative Tukey box-andwhiskers of IL-10 secreting T and B cells in HNP, HP, ANP and AP, including the PP evaluation of pregnant women. All comparisons were performed with the Mann-Whitney U test, except paired groups comparisons (AP vs AP PP; and HP vs HP PP), which were performed with the Wilcoxon test.

Central line: median; box: interquartile range; whiskers, range; dots, outliers. ${ }^{*} P<.05 ;{ }^{*}{ }^{*}<.001$. 
Although all the asthmatic women took asthma medication during pregnancy, just $13(54.2 \%)$ continued to do so (ICS therapy and/or LABA and antileukotrienes) in the postpartum period. The postpartum measurements were performed a median of 44 (8) days after delivery.

\section{Increase in $\mathrm{CD}^{+} \mathrm{CD} 25^{\mathrm{Hi}} \mathrm{Foxp}^{+}$Tregs in ANP Women and in AP Women Postpartum}

$\mathrm{CD} 4{ }^{+} \mathrm{CD} 25^{\mathrm{Hi}} \mathrm{Foxp}^{+}$Treg frequencies were significantly increased in ANP women compared with HNP women $(P=.002)$ (Figure 4A).

No differences were observed between third-trimester and postpartum results in either AP or HP women. On comparing Treg levels for the third trimester between pregnant and nonpregnant women, no significant differences were found between AP and ANP women or between HP and HNP women. Nevertheless, in the postpartum period, Tregs were significantly increased in both AP and HP women compared with HNP women (AP vs HNP, $P=.041$; HP vs HNP, $P=.005$ ). These results would seem to point towards an increase in Tregs after pregnancy.

\section{Foxp3 Expression Is Increased in Asthmatic Women, but Varies From Pregnancy to Postpartum}

We also studied Foxp3 expression in $\mathrm{CD} 4^{\mathrm{Dim}} \mathrm{CD} 25^{\mathrm{Hi}}$ Tregs (Figure 4A), and found that it was significantly increased $(P<.001)$ in ANP compared with HNP women.

During pregnancy, and at least until delivery (data not shown), decreased Foxp3 expression in CD $4^{\mathrm{Dim}} \mathrm{CD} 25^{\mathrm{Hi}}$ Tregs was observed in both AP and HP women. The decrease was more pronounced in the HP group, where expression levels were significantly lower $(P=.007)$ than those observed in the AP group. Both groups of women had significantly downregulated Foxp3 expression in the third trimester of pregnancy compared with both HNP and ANP women $(P<.001$ in both cases). Foxp3 expression levels increased significantly $(P<.001)$ in AP and HP women postpartum compared with values observed in the third trimester of pregnancy. Postpartum, both the asthmatic and healthy women achieved expression levels similar to those observed in their nonpregnant counterparts.

\section{CD24 ${ }^{\mathrm{Hi} C D} 38^{\mathrm{Hi}}$ Regulatory B cells Are Increased Postpartum in AP and HP Women}

As shown in Table 2, CD24 ${ }^{\mathrm{Hi}} \mathrm{CD} 27^{+}$Breg levels were similar in all groups of women studied at both time points. Thus, no differences were observed between pregnancy and postpartum levels in either AP or HP women (Figure 4B). $\mathrm{CD} 24{ }^{\mathrm{Hi}} \mathrm{CD} 38^{\mathrm{Hi}} \mathrm{Bregs}$, a transitional subset of B cells, displayed mostly pregnancy-associated changes. Comparable levels were observed in ANP and HNP women. No differences were observed between AP and HP women at either of the time points analyzed. During pregnancy, CD $24{ }^{\mathrm{Hi}} \mathrm{CD} 38^{\mathrm{Hi}}$ Breg levels displayed similar fluctuations to those observed for Foxp3 levels. Reduced proportions of circulating CD24 ${ }^{\mathrm{Hi}} \mathrm{CD} 38^{\mathrm{Hi}}$ Bregs were observed during pregnancy in AP and HP women compared with nonpregnant controls $(P \leq .004)$. In both groups of pregnant women, $\mathrm{CD} 24^{\mathrm{Hi}} \mathrm{CD} 38^{\mathrm{Hi}}$ Breg frequencies were significantly increased postpartum compared with thirdtrimester levels $(P<.001)$ but also compared with levels in ANP and HNP women $(P \leq .003)$.

In the third trimester, a positive correlation was found between $\mathrm{CD} 24^{\mathrm{Hi}} \mathrm{CD} 38^{\mathrm{Hi}}$ Bregs and Foxp3 expression in HP women $(P=.002, \mathrm{r}=0.457$; Spearman correlation test $)$, but the significance was lost postpartum.

In nonpregnant women, percentages of IL-10-secreting $\mathrm{T}$ cells (CD3, CD4, and CD8) were higher in asthmatics than in healthy controls $(P=.024$ for CD $3 ; P=.034$ for CD4; $P=.009$ for $\mathrm{CD} 8)$. In the third trimester, however, AP women had significantly increased percentages of IL-10-secreting $B$ cells, but not T cells, compared with both HP $(P=.022)$ and HNP $(P=.008)$ women. Postpartum, IL-10-secreting T cells (CD3 and CD8) were again increased in AP compared with HNP women $(P=.046$ for CD3 and $P=.016$ for CD8); a similar result was observed for IL-10-secreting $\mathrm{B}$ cells $(P=.031)$.

Table 2. Percentages and Absolute Counts of T- and B-Cell Subsets in Pregnant and Nonpregnant Women With and Without Asthma ${ }^{\mathrm{a}}$

\begin{tabular}{|c|c|c|c|c|c|c|}
\hline Cell Subsets & $\begin{array}{l}\text { AP Women } \\
\quad(n=24)\end{array}$ & $\begin{array}{l}\text { AP Women PP } \\
\quad(n=24)\end{array}$ & $\begin{array}{l}\text { ANP Women } \\
\quad(n=32)\end{array}$ & $\begin{array}{l}\text { HP Women } \\
\quad(n=43)\end{array}$ & $\begin{array}{l}\text { HP Women PP } \\
\quad(n=43)\end{array}$ & $\begin{array}{l}\text { HNP Women } \\
\quad(n=35)\end{array}$ \\
\hline \multicolumn{7}{|l|}{ Regulatory T cells } \\
\hline $\left.\mathrm{CD} 4^{+} \mathrm{CD} 25^{\mathrm{Hi}} \mathrm{Foxp}^{+}, \%\right)$ & $6.14(1.54)$ & $5.90(2.43)$ & $6.88(2.17)$ & $6.07(3.44)$ & $6.63(2.85)$ & $5.48(1.69)$ \\
\hline $\mathrm{CD}^{+} \mathrm{CD} 25^{\mathrm{Hi}} \mathrm{Foxp}^{+}$, cells $/ \mu \mathrm{L}$ & $52(22)$ & $65(29)$ & $83(33)$ & $50(25)$ & $71(39)$ & $56(31)$ \\
\hline Foxp3 expression in $\mathrm{CD} 4{ }^{\mathrm{Dim}} \mathrm{CD} 25^{\mathrm{Hi}}$ & $1.64(1.26)$ & $1.94(0.46)$ & $2.09(0.43)$ & $1.49(0.19)$ & $1.93(0,30)$ & $1.80(0.25)$ \\
\hline \multicolumn{7}{|l|}{ Regulatory B cells } \\
\hline $\mathrm{CD} 24^{\mathrm{Hi}} \mathrm{CD} 27^{+}, \%$ & $25.47(16.75)$ & $27.26(20.46)$ & $31.77(13.37)$ & $26.92(15.02)$ & $25.76(14.30)$ & $27.46(49.80)$ \\
\hline $\mathrm{CD} 24^{\mathrm{Hi}} \mathrm{CD} 27^{+}$, cells $/ \mu \mathrm{L}$ & $45(47)$ & $59(45)$ & $102(97)$ & $44(41)$ & $57(47)$ & $54(40)$ \\
\hline $\mathrm{CD} 24^{\mathrm{Hi}} \mathrm{CD} 38^{\mathrm{Hi}}, \%$ & $1.87(2.97)$ & $7.13(8.84)$ & $3.84(2.74)$ & $1.42(1.38)$ & $5.62(5.58)$ & $3.63(2.48)$ \\
\hline $\mathrm{CD} 24^{\mathrm{Hi}} \mathrm{CD} 38^{\mathrm{Hi}}$, cells $/ \mu \mathrm{L}$ & $3(4)$ & $14(25)$ & $12(7)$ & $2(2)$ & $11(14)$ & $8(8)$ \\
\hline \multicolumn{7}{|l|}{ IL-10 secreting cells } \\
\hline IL $10^{+} \mathrm{CD}^{+} \mathrm{T}$ cells, $\%$ & $0.83(0.69)$ & $0.91(0.70)$ & $0.94(0.46)$ & $0.77(0.47)$ & $0.83(0.50)$ & $0.72(0.57)$ \\
\hline $\mathrm{IL} 10^{+} \mathrm{CD}^{+} \mathrm{CD}^{+}\left(\mathrm{CD} 8^{-}\right) \mathrm{T}$ cells, $\%$ & $1.00(0.76)$ & $1.03(0.78)$ & $1.04(0.71)$ & $0.92(0.54)$ & $0.95(0.53)$ & $0.84(0.54)$ \\
\hline $\mathrm{IL} 0^{+} \mathrm{CD}^{+} \mathrm{CD}^{+} \mathrm{T}$ cells, $\%$ & $0.66(0.69)$ & $0.65(0.86)$ & $0.73(0.51)$ & $0.49(0.55)$ & $0.59(0.47)$ & $0.40(0.59)$ \\
\hline $\mathrm{IL}_{10} 0^{+} \mathrm{CD} 19^{+} \mathrm{B}$ cells, $\%$ & $1.26(0.67)$ & $1.24(0.83)$ & $1.04(0.73)$ & $1.00(0.90)$ & $1.17(0.91)$ & $0.92(0.70)$ \\
\hline
\end{tabular}

Abbreviations: ANP, asthmatic nonpregnant; $A P$, asthmatic pregnant; HNP, healthy nonpregnant; HP, healthy pregnant; PP, postpartum.

${ }^{a}$ All results are presented as median (IQR). 
Interestingly, during the postpartum period, HP women had higher percentages of IL-10-secreting B cells than their nonpregnant counterparts $(P=.019)$, suggesting that IL-10 production by $\mathrm{B}$ cells is impaired during healthy pregnancies. On analyzing levels in the pregnancy groups, no significant changes were observed from pregnancy to postpartum in asthmatic women, but a significant increase in IL-10-secreting $\mathrm{B}$ cells was detected in healthy women in the postpartum period $(P=.037)$, as shown in Figure 4C.

\section{Discussion}

Regulatory cells have an important role in immune tolerance and inflammation. To our knowledge this is the first study to report variations in regulatory $\mathrm{T}$ - and B-cell subsets and to describe IL-10 secretion profiles in women with asthma between the third trimester of pregnancy and postpartum. While Treg populations do not appear to vary significantly through this period, CD $24{ }^{\mathrm{Hi}} \mathrm{CD} 38^{\mathrm{Hi}}$ Bregs were found to be decreased in the third trimester of pregnancy and to be considerably increased in the postpartum period in both asthmatic and healthy women. Moreover, the reduction observed in Foxp3 expression in Tregs in late pregnancy (and at least until delivery) was no longer evident 6 weeks after delivery. Women with asthma were also found to have more IL-10-producing T cells than HNP women. In the third trimester of pregnancy, atopic women had higher levels of IL-10-secreting B cells than their healthy counterparts, but no significant differences were observed postpartum.

Tregs are involved in several human diseases. During pregnancy, their numbers increase in the early stages and decline from mid-gestation onwards [5]. Our observation of similar Treg frequencies in women during the third trimester of pregnancy and nonpregnant controls supports previous reports [5,22]. Wegienka et al [23] reported a progressive increase in Treg percentages from the prenatal period up to 12 months postpartum in both atopic and nonatopic patients, as we observed in our patients. Although we used different time points to Wegienka et al, we also found that both AP and HP women had higher percentages of Tregs 6 weeks after delivery than healthy nonpregnant controls. Differences between studies could be due to variations in cell identification strategies, gestational periods analyzed, or use of animal models.

Our results show that pregnant and nonpregnant women with controlled asthma have higher Treg percentages than HNP women and that these frequencies are maintained postpartum. Increased Treg frequencies have been reported for children with asthma under ICS treatment compared with nonasthmatic agematched controls [24]. Nevertheless, Bohacs et al [15] reported a comparable prevalence of Tregs in healthy nonpregnant and asthmatic pregnant and nonpregnant women, although values were higher in asthmatics. Similar Treg values were seen for asthmatic patients taking ICSs, regardless of frequency of use. We also observed comparable Treg frequencies in treated and untreated AP women in the postpartum period (data not shown). Considering that all AP women had been taking ICS during pregnancy, the similar postpartum values observed in treated and untreated women suggest that ICS may continue to have an impact on the frequency of circulating Tregs even after treatment is stopped. ICS treatment also upregulates Foxp3 expression. Karagiannidis et al [25] reported that Foxp3 expression was significantly increased in ICS-treated asthmatic patients compared with healthy controls. By contrast, Provoost et al [26] only reported increased expression in ICS-treated asthmatics compared with untreated asthmatics but not healthy controls. Methodological differences could explain these opposing results, but our data seem to support the findings of Karagianiddis et al. In our study, ANP women had higher Foxp3 expression levels than HNP women, but during pregnancy, higher expression levels were also observed in AP women compared with HP women. Yet, Foxp3 levels were considerably decreased in atopic and healthy women during pregnancy. Progesterone receptors were recently identified in Tregs [27], supporting the immunomodulatory potential of pregnancy hormones. Without compromising the regulatory potential of Tregs during pregnancy, and even promoting their proliferation [28] and proportions [29], progesterone and $17 \beta$-estradiol are thought to reduce Foxp 3 expression in Tregs in second-trimester pregnant women [30]. Our detection of a decrease in Foxp3 expression during the third trimester of gestation supports and complements these findings. In addition, we observed this pregnancy-derived decrease in Foxp3 expression in ICS-treated atopic women, although levels were higher than those observed in their healthy counterparts. Considering that Foxp3 expression can be induced in activated $\mathrm{T}$ cells and that our study did not assess the functional status of Tregs, we can only speculate that Treg function is normal in AP women. This speculation, however, is supported by the protective role described for Tregs in terms of the suppression of asthma manifestations [31] and the fact that the AP women had controlled asthma at the time of recruitment. Nevertheless, further studies are needed to complete and confirm our observations.

Foxp3 expression levels normalized in both atopic and healthy women postpartum; they returned to levels found in nonpregnant controls, reinforcing the theory that pregnancy modulates Foxp3 expression.

One of the novel aspects of our study is the evaluation of Breg levels in asthmatic pregnant women. Although the regulatory capacities of B cells were recently reported [32], there is a lack of consensus on their phenotype [33]. IL-10mediated regulatory functions have been proposed for both $\mathrm{CD} 24{ }^{\mathrm{Hi}} \mathrm{CD} 27^{+}$and $\mathrm{CD} 24{ }^{\mathrm{Hi}} \mathrm{CD} 38^{\mathrm{Hi}} \mathrm{B}$ cell subsets $[10,34]$. Decreased frequencies of $\mathrm{CD} 24{ }^{\mathrm{Hi}} \mathrm{CD} 27^{+}$Bregs have been observed in patients with asthma and/or allergic rhinitis $[10,35]$, although increased $\mathrm{CD} 24{ }^{\mathrm{Hi}} \mathrm{CD} 38^{\mathrm{Hi}} \mathrm{Breg}$ frequencies have been observed in asthmatic patients not taking medication [10]. In our study, there were no differences in Breg subsets on comparing asthmatic and nonasthmatic patients, but our patients were all taking medication at recruitment. Similarly to reports for Tregs [24], our data suggest that the beneficial effects of treatments such as ICS in atopic diseases may include the normalization of Breg frequencies.

$\mathrm{CD} 24{ }^{\mathrm{Hi}} \mathrm{CD} 38^{\mathrm{Hi}}$ Bregs are modulated by pregnancy. Pregnancy is associated with B cell lymphopenia and B cell lymphopoiesis arrest [13], probably leading to a decrease in circulating transitional B-cell subsets, such as $\mathrm{CD} 24{ }^{\mathrm{Hi}} \mathrm{CD} 38^{\mathrm{Hi}}$ 
Bregs. In our series, the reduction in $\mathrm{CD} 244^{\mathrm{Hi}} \mathrm{CD} 38^{\mathrm{Hi}}$ Breg frequencies observed during pregnancy was considerably overturned postpartum, with levels surpassing those observed in nonpregnant controls, supporting the recovery of the maternal immune system after gestation. In mice, transitional B cells express high levels of prolactin receptors, and hyperprolactinemia has been shown to increase transitional but not mature B cells [36]. A prolactin-mediated response may thus explain the accumulation of transitional B cells in the postpartum period, when hormone levels are up to 30 times higher than before pregnancy [37].

Promotion of Treg differentiation is believed to be one of the mechanisms underlying $\mathrm{CD} 24^{\mathrm{Hi}} \mathrm{CD} 38^{\mathrm{Hi}}$ Breg function in healthy individuals [34]. Thus, the increase observed in $\mathrm{CD} 4{ }^{+} \mathrm{CD} 25^{\mathrm{Hi}} \mathrm{Foxp} 3^{+}$Treg frequencies in HP and AP postpartum, which has been previously reported [23], may be mediated by $\mathrm{CD} 24^{\mathrm{Hi}} \mathrm{CD} 38^{\mathrm{Hi}}$ Bregs. Recent experimental data also concluded that $\mathrm{CD} 24^{\mathrm{Hi}} \mathrm{CD} 38^{\mathrm{Hi}}$ Bregs promote Foxp3 expression in cocultured $\mathrm{CD}^{+} \mathrm{T}$ cells [34]. In our study, Foxp3 expression and $\mathrm{CD} 24{ }^{\mathrm{Hi}} \mathrm{CD} 38^{\mathrm{Hi}}$ Bregs displayed similar changes from pregnancy to postpartum, and there was a positive correlation between these parameters in HP women, reinforcing the idea that Bregs modulate Tregs.

The profile of CD $24{ }^{\mathrm{Hi}} \mathrm{CD} 38^{\mathrm{Hi}}$ Bregs and Foxp3 expression is comparable in asthmatic and nonasthmatic women, supporting the existence of a pregnancy-derived pattern, regardless of the presence of asthma or rhinitis or treatment.

Studies that have analyzed IL-10 production by peripheral blood mononuclear cells (PBMCs) during pregnancy have described similar levels before pregnancy and during late pregnancy [38]. In line with these reports, our data showed that IL-10-secreting T and B cells in healthy women during the third trimester of gestation were similar to those observed in nonpregnant counterparts. However, in the postpartum period, HP women had increased frequencies of IL- $10^{+} \mathrm{B}$ cells after lipopolysaccharide stimulation. One possible explanation is the postpartum increase in circulating CD24 ${ }^{\mathrm{Hi}} \mathrm{CD} 38^{\mathrm{Hi}}$ Bregs (the subset in which IL-10 secretion is mainly described in B cells) $[32,34]$. Other studies have analyzed the production of IL-10 in asthmatic and allergic women through total PBMC secretion and serum levels [39,40]. Although no differences in PBMC production were detected between asthmatic and nonasthmatic women [39], IL-10 serum levels were found to be increased in allergic mothers (at delivery) and their children [40]. To our knowledge, our study is the first to report distinct profiles of IL-10-secreting $\mathrm{T}$ and $\mathrm{B}$ cells in pregnant and nonpregnant asthmatic women. The ANP group had increased frequencies of IL-10-secreting T cells, but during pregnancy asthmatic women had higher percentages of IL-10-secreting B cells than healthy women. Nonetheless, it should be noted that Tregs, together with other subsets of T cells, such as $\mathrm{T}_{\mathrm{H}} 2$ cells, can secrete IL-10 [4]. $\mathrm{T}_{\mathrm{H}} 2$ cells, which are associated with both pregnancy and allergic diseases, may be responsible for the similar levels observed in AP, ANP, and HP women. However, the IL-10-secreting capacity of $\mathrm{B}$ cells in AP women during pregnancy was distinct to that observed in both HP and HNP women, with similar (vs HP) or even lower (vs HNP) frequencies of CD24 ${ }^{\mathrm{Hi} C D} 38^{\mathrm{Hi}}$ Bregs observed. Supporting observations in ANP women, during the postpartum period, AP women also had higher frequencies of IL-10-secreting B and T cells than HNP women.

At the postpartum follow-up, we discovered that several of the women had stopped taking their asthmatic or allergic rhinitis treatment. Considering the distinguishing features of immune profiles in the postpartum period, we compared women who had stopped treatment with those who had continued to use it, and found that the parameters studied were similar in both subgroups, indicating thus that they are independent of treatment.

Ideally, we should have monitored AP women before pregnancy and at more points during pregnancy, but this would have been complicated from both a financial and practical perspective. Nevertheless, our results confirm that important immune events occur during the third trimester of pregnancy and that the situation normalizes postpartum.

In conclusion, pregnant women with controlled asthma have a similar profile to their healthy counterparts, although they do have a few distinctive features, mainly related to Foxp3 expression. The changes observed postpartum reinforce the idea of a pregnancy-dependent, probably hormone-driven, effect. More studies will clarify if the parameters we have analyzed can be used to assess complications during pregnancy in women with asthma and investigate possible influences on the immune profile of the offspring of asthmatic women.

\section{Acknowledgements}

The authors would like to thank Tiago Domingues for providing technical support with the statistical analysis.

\section{Funding}

The authors declare that no funding was received for this study.

\section{Conflicts of Interest}

The authors declare that they have no conflicts of interests.

\section{References}

1. Namazy J, Schatz M. The Treatment of Allergic Respiratory Disease During Pregnancy. J Investig Allergol Clin Immunol. 2016;26(1):1-7; quiz 2p following 7.

2. Xu R, DeMauro SB, Feng $R$. The impact of parental history on children's risk of asthma: a study based on the National Health and Nutrition Examination Survey-III. J Asthma Allergy. 2015:8:51-61.

3. Piccinni MP, Lombardelli L, Logiodice F, Kullolli O, Romagnani S, Le Bouteiller P. T helper cell mediated-tolerance towards fetal allograft in successful pregnancy. Clin Mol Allergy. 2015;13(1):9.

4. Halonen M, Lohman IC, Stern DA, Spangenberg A, Anderson D, Mobley S, Ciano K, Peck M, Wright AL. Th1/Th2 patterns and balance in cytokine production in the parents and infants of a large birth cohort. J Immunol. 2009;182(5):3285-93.

5. Zhao JX, Zeng YY, Liu Y. Fetal alloantigen is responsible for the expansion of the CD4(+)CD25(+) regulatory T cell pool during pregnancy. J Reprod Immunol. 2007;75(2):71-81. 
6. Hartl D, Koller B, Mehlhorn AT, Reinhardt D, Nicolai T, Schendel DJ, Griese M, Krauss-Etschmann S. Quantitative and functional impairment of pulmonary CD4+CD25hi regulatory T cells in pediatric asthma. J Allergy Clin Immunol. 2007;119(5):125866.

7. Lin YL, Shieh CC, Wang JY. The functional insufficiency of human CD4+CD25 high T-regulatory cells in allergic asthma is subjected to TNF-alpha modulation. Allergy. 2008;63(1):6774.

8. Bohm L, Maxeiner J, Meyer-Martin H, Reuter S, Finotto S, Klein M, Schild H, Schmitt E, Bopp T, Taube C. IL-10 and regulatory $T$ cells cooperate in allergen-specific immunotherapy to ameliorate allergic asthma. J Immunol. 2015;194(3):887-97.

9. Drake LY, lijima K, Hara K, Kobayashi T, Kephart GM, Kita H. $B$ cells play key roles in th2-type airway immune responses in mice exposed to natural airborne allergens. PLoS One. 2015; 10(3):e0121660.

10. van der Vlugt $L E$, Mlejnek $E$, Ozir-Fazalalikhan $A$, Janssen Bonas M, Dijksman TR, Labuda LA, Schot R, Guigas B, Moller GM, Hiemstra PS, Yazdanbakhsh M, Smits HH. CD24(hi) CD27(+) B cells from patients with allergic asthma have impaired regulatory activity in response to lipopolysaccharide. Clin Exp Allergy. 2014;44(4):517-28.

11. Amu S, Saunders SP, Kronenberg M, Mangan NE, Atzberger A, Fallon PG. Regulatory B cells prevent and reverse allergic airway inflammation via FoxP3-positive T regulatory cells in a murine model. J Allergy Clin Immunol. 2010;125(5):1114-24 e8.

12. Tilburgs T, Roelen DL, van der Mast BJ, van Schip JJ, Kleijburg $\mathrm{C}$, de Groot-Swings GM, Kanhai HH, Claas FH, Scherjon SA. Differential distribution of CD4(+)CD25(bright) and CD8(+) CD28(-) T-cells in decidua and maternal blood during human pregnancy. Placenta. 2006;27 Suppl A:S47-53.

13. Muzzio DO, Soldati R, Ehrhardt J, Utpatel K, Evert $M$, Zenclussen $A C$, Zygmunt $M$, Jensen $F$. B cell development undergoes profound modifications and adaptations during pregnancy in mice. Biol Reprod. 2014;91(5):115.

14. Rolle L, Memarzadeh Tehran M, Morell-Garcia A, Raeva Y, Schumacher A, Hartig R, Costa SD, Jensen F, Zenclussen AC. Cutting edge: IL-10-producing regulatory $B$ cells in early human pregnancy. Am J Reprod Immunol. 2013;70(6):44853.

15. Bohacs A, Cseh A, Stenczer B, Muller V, Galffy G, Molvarec A, Rigo J, Jr., Losonczy G, Vasarhelyi B, Tamasi L. Effector and regulatory lymphocytes in asthmatic pregnant women. Am J Reprod Immunol. 2010;64(6):393-401.

16. Toldi G, Molvarec A, Stenczer B, Muller V, Eszes N, Bohacs A, Bikov A, Rigo J, Jr., Vasarhelyi B, Losonczy G, Tamasi L. Peripheral $T(h) 1 / T(h) 2 / T(h) 17 /$ regulatory $T$-cell balance in asthmatic pregnancy. Int Immunol. 2011;23(11):669-77.

17. Ostensen $M$, Sicher P, Forger F, Villiger PM. Activation markers of peripheral blood mononuclear cells in late pregnancy and after delivery: a pilot study. Ann Rheum Dis. 2005;64(2):31820.

18. Bousquet J, Khaltaev N, Cruz AA, Denburg J, Fokkens WJ, Togias A, Zuberbier T, Baena-Cagnani CE, Canonica GW, Van Weel C, Agache I, Aït-Khaled N, Bachert C, Blaiss MS, Bonini $S$, Boulet LP, Bousquet PJ, Camargos P, Carlsen KH, Chen $Y$, Custovic A, Dahl R, Demoly P, Douagui H, Durham SR, Van
Wijk RG, Kalayci O, Kaliner MA, Kim YY, Kowalski ML, Kuna P, Le LTT, Lemiere C, Li J, Lockey RF, Mavale-Manuel S, Meltzer EO, Mohammad Y, Mullol J, Naclerio R, O'Hehir RE, Ohta K, Ouedraogo S, Palkonen S, Papadopoulos N, Passalacqua G, Pawankar R, Popov TA, Rabe KF, Rosado-Pinto J, Scadding GK, Simons FER, Toskala E, Valovirta E, Van Cauwenberge $P_{\text {, }}$ Wang DY, Wickman M, Yawn BP, Yorgancioglu A, Yusuf OM, Zar H, Annesi-Maesano I, Bateman ED, Kheder AB, Boakye DA, Bouchard J, Burney P, Busse WW, Chan-Yeung M, Chavannes $\mathrm{NH}$, Chuchalin A, Dolen WK, Emuzyte R, Grouse L, Humbert M, Jackson C, Johnston SL, Keith PK, Kemp JP, Klossek JM, Larenas-Linnemann D, Lipworth B, Malo JL, Marshall GD, Naspitz C, Nekam K, Niggemann B, Nizankowska-Mogilnicka E, Okamoto Y, Orru MP, Potter P, Price D, Stoloff SW, Vandenplas 0 , Viegi $G$, Williams D. Allergic Rhinitis and its Impact on Asthma (ARIA) 2008*. Allergy. 2008;63:8-160.

19. From the Global Strategy for Asthma Management and Prevention, Global Initiative for Asthma (GINA) 2014. Available from: http://www.ginasthma.org/. Assessed September 30, 2015.

20. From the Global Strategy for Asthma Management and Prevention, Global Initiative for Asthma (GINA) 2015. Available from: http://www.ginasthma.org/. Assessed September 30, 2015.

21. Yanaba K, Bouaziz JD, Haas KM, Poe JC, Fujimoto M, Tedder TF. A regulatory $B$ cell subset with a unique CD1dhiCD5+ phenotype controls T cell-dependent inflammatory responses. Immunity. 2008;28(5):639-50.

22. Loewendorf Al, Nguyen TA, Yesayan MN, Kahn DA. Normal human pregnancy results in maternal immune activation in the periphery and at the uteroplacental interface. PLoS One. 2014;9(5):e96723.

23. Wegienka G, Havstad S, Bobbitt KR, Woodcroft KJ, Zoratt EM, Ownby DR, Cole Johnson C. Within-woman change in regulatory $T$ cells from pregnancy to the postpartum period. J Reprod Immunol. 2011;88(1):58-65.

24. Singh AM, Dahlberg $P$, Burmeister $K$, Evans MD, Gangnon $R$, Roberg KA, Tisler C, Dasilva D, Pappas T, Salazar L, Lemanske RF, Jr., Gern JE, Seroogy CM. Inhaled corticosteroid use is associated with increased circulating $T$ regulatory cells in children with asthma. Clin Mol Allergy. 2013;11(1):1.

25. Karagiannidis C, Akdis M, Holopainen P, Woolley NJ, Hense G, Ruckert B, Mantel PY, Menz G, Akdis CA, Blaser K, SchmidtWeber CB. Glucocorticoids upregulate FOXP3 expression and regulatory $T$ cells in asthma. J Allergy Clin Immunol. 2004; 114(6):1425-33.

26. Provoost $S$, Maes T, van Durme YM, Gevaert P, Bachert $C$, Schmidt-Weber CB, Brusselle GG, Joos GF, Tournoy KG. Decreased FOXP3 protein expression in patients with asthma. Allergy. 2009;64(10):1539-46.

27. Areia A, Vale-Pereira $S$, Alves V, Rodrigues-Santos P, Moura $P$, Mota-Pinto A. Membrane progesterone receptors in human regulatory $T$ cells: a reality in pregnancy. BJOG. 2015;122(11):1544-50.

28. Prieto GA, Rosenstein Y. Oestradiol potentiates the suppressive function of human CD4 CD25 regulatory T cells by promoting their proliferation. Immunology. 2006;118(1):58-65.

29. Mao G, Wang J, Kang Y, Tai P, Wen J, Zou Q, Li G, Ouyang $H$, Xia G, Wang B. Progesterone increases systemic and local 
uterine proportions of CD4+CD25+ Treg cells during midterm pregnancy in mice. Endocrinology. 2010;151(11):5477-88.

30. Mjosberg J, Svensson J, Johansson E, Hellstrom L, Casas $R$, Jenmalm MC, Boij R, Matthiesen L, Jonsson Jl, Berg G, Ernerudh J. Systemic reduction of functionally suppressive CD4dimCD25highFoxp3+ Tregs in human second trimester pregnancy is induced by progesterone and 17 beta-estradiol. J Immunol. 2009;183(1):759-69.

31. Thorburn AN, Hansbro PM. Harnessing regulatory T cells to suppress asthma: from potential to therapy. Am J Respir Cell Mol Biol. 2010;43(5):511-9.

32. Blair PA, Norena LY, Flores-Borja F, Rawlings DJ, Isenberg DA, Ehrenstein MR, Mauri C. CD19(+)CD24(hi)CD38(hi) B cells exhibit regulatory capacity in healthy individuals but are functionally impaired in systemic Lupus Erythematosus patients. Immunity. 2010;32(1):129-40.

33. Braza F, Chesne J, Castagnet S, Magnan A, Brouard S. Regulatory functions of $\mathrm{B}$ cells in allergic diseases. Allergy. 2014;69(11):1454-63.

34. Flores-Borja F, Bosma A, Ng D, Reddy V, Ehrenstein MR, Isenberg DA, Mauri C. CD19+CD24hiCD38hi B cells maintain regulatory $T$ cells while limiting $\mathrm{TH} 1$ and $\mathrm{TH} 17$ differentiation. Sci Transl Med. 2013;5(173):173ra23.

35. Kamekura R, Shigehara K, Miyajima $S$, Jitsukawa $S$, Kawata K, Yamashita K, Nagaya T, Kumagai A, Sato A, Matsumiya H, Ogasawara N, Seki N, Takano K, Kokai Y, Takahashi H, Himi T, Ichimiya S. Alteration of circulating type 2 follicular helper $\mathrm{T}$ cells and regulatory B cells underlies the comorbid association of allergic rhinitis with bronchial asthma. Clin Immunol. 2015;158(2):204-11.

36. Ledesma-Soto Y, Blanco-Favela F, Fuentes-Panana EM, TesoroCruz E, Hernandez-Gonzalez R, Arriaga-Pizano L, LegorretaHaquet MV, Montoya-Diaz E, Chavez-Sanchez L, CastroMussot ME, Chavez-Rueda AK. Increased levels of prolactin receptor expression correlate with the early onset of lupus symptoms and increased numbers of transitional-1 B cells after prolactin treatment. BMC Immunol. 2012;13:11.

37. Zen $M$, Ghirardello $A$, laccarino L, Tonon M, Campana C, Arienti S, Rampudda M, Canova M, Doria A. Hormones, immune response, and pregnancy in healthy women and SLE patients. Swiss Med Wkly. 2010;140(13-14):187-201.

38. Hanna N, Hanna I, Hleb M, Wagner E, Dougherty J, Balkundi D, Padbury J, Sharma S. Gestational age-dependent expression of IL-10 and its receptor in human placental tissues and isolated cytotrophoblasts. J Immunol. 2000;164(11):5721-8.

39. Vanders RL, Gibson PG, Wark PA, Murphy VE. Alterations in inflammatory, antiviral and regulatory cytokine responses in peripheral blood mononuclear cells from pregnant women with asthma. Respirology. 2013;18(5):827-33.

40. Prokesova L, Lodinova-Zadnikova R, Zizka J, Kocourkova I, Novotna O, Petraskova P, Sterzl I. Cytokine levels in healthy and allergic mothers and their children during the first year of life. Pediatr Allergy Immunol. 2006;17(3):175-83.

\footnotetext{
Manuscript received January 15, 2016; accepted for publication June 7, 2016.
}

\section{- Catarina Martins}

Imunologia

NOVA Medical School | Faculdade de Ciências Médicas Campo dos Mártires da Pátria, 130

1169-056 Lisboa, Portugal

E-mail: catarina.martins@nms.unl.pt 